УДК 81'371

DOI https://doi.org/10.52726/as.humanities/2021.3.35

\author{
А. В. ШЕВЧУК \\ кандидат філологічних наук, \\ дочент кафедри іноземної та української філології, \\ Луцький національний технічний університет, м. Луцьк, Украӥна \\ Електронна пошта: a.shevchuk@lutsk-ntu.com.ua \\ https://orcid.org/0000-0002-5005-3800
}

\author{
А. І. ЯНОВЕЦЬ \\ кандидат філологічних наук, доцент, \\ дочент кафедри іноземної та української філології, \\ Луиький національний технічний університет, м. Луиьк, Украӥна \\ Електронна nошта: angelikayanovec@lutsk-ntu.com.ua \\ https://orcid.org/0000-0002-1626-5244
}

\title{
ІНТЕРПРЕТАЦІЯ ПАРАМЕТРА «ЗАГАЛЬНИЙ РОЗМІР» У ТЛУМАЧЕННЯХ ЗООНІМІЧНОЇ ЛЕКСИКИ
}

Пропонована наукова розвідка присвячена питанню інтерпретації параметра «загальний розмір» у тлумаченнях зоонімічної лексики, вибраної із трьох авторитетних лексикографічних джерел сучасної англійської мови. У результаті дослідження виявлено, що, представляючи просторові характеристики об'єктів матеріального світу на мовному рівні, параметричні прикметники характеризуються, з одного боку, простотою інтерпретації та визначення їх значення. Віднесеність їх до емпіричних прикметників, що відбивають ознаки об' єктів, які сприймаються перцептивно, на перший погляд, робить їх семантику відносно прозорою та стійкою. 3 іншого боку, відсутність чітких фіксованих меж їх вживання, виразно сформованих стандартів порівняльних конструкцій дає можливість подальшого їх семантичного розвитку та девіації в інтерпретації розмірних характеристик об'єктів. Тому виявлення особливостей використання параметричних прикметників та лексичних конструкцій на позначення загальної величини референтних об'єктів реального світу є актуальною проблемою 3 погляду як теоретичного, так і практичного аспектів лексикографічного представлення лексем-зоонімів у різних типах лінгвістичних словників. Зокрема, зазначено, що дефініції зоонімів вводять інформацію про загальний розмір тварини на початку словникового визначення. У такому разі найбільшою частотністю володіють прикметники “large” та “small”, що вказують на загальне враження від тварини. Також спостерігаємо використання порівняльних конструкцій, у яких отримуємо вказівку на подібну тварину, що спрощує ідентифікацію референта читачем або ж додатково вносить дані про розмірне співвідношення. У чималій кількості дефініцій зоонімів опущено параметр «загальний розмір», однак це стосується переважно загальновідомих представників світу фауни, розпізнання яких людиною зазвичай не викликає труднощів. У статті обговорюються питання параметричної норми, стандарту, а також градуювання прикметників. Загалом визначено, що пропоновані прийоми лексикографічного опису зоонімічної лексики потребують удосконалення та уніфікованого підходу, оскільки автори словників часто не дотримуються принципів адекватності та достатності, що своєю чергою приводить до труднощів інтерпретації інформації, поданої у словниковій статті.

Ключові слова: лексикографія, тлумачний словник, зоонім, прикметник, «загальний розмір».

Постановка наукової проблеми та її значення. Усі предмети та явища навколишнього світу перебувають між собою у певних зв'язках, найуніверсальнішими з яких є власне просторові. Розмір або ж величина об'єктів реальної дійсності - їхня невіддільна властивість. Адекватне розпізнання та використання таких властивостей людиною у своїй повсякденній діяльності вимагає їхнього повного закріплення в мовному середовищі. Однією з найуживаніших і високочастотних груп лексики у будь-якій мові вважаються прикметники на позначення категорії розміру. Це емпіричні прикметники, які відбивають ознаки об'єктів, сприйняті органами чуттів.

Досить рідко словниковий опис окремої лексичної одиниці, референт якої апріорі володіє певним набором ознак, обходиться без використання цієї категорії прикметників. У статті розглянуто одну із найчисельніших лексико- 
семантичних груп англійської мови, а саме зооніми. Словникові дефініції назв представників тваринного світу, наведені в тлумачних словниках сучасної англійської мови, зазвичай одразу знайомлять читача 3 інформацією про «загальний розмір» тварини, а вже згодом про окремі особливості зовнішнього вигляду, спосіб поведінки, ареал поширення, значення для людини тощо. Все ж набір поданих у словникових тлумаченнях ознак не завжди сприяє правильній та миттєвій ідентифікації того чи іншого фаунопредставника. Тому набуває актуальності питання вивчення особливостей вказівки величини референтного об'єкта та адекватної достатності лексикографічного опису зоонімічної лексики таким способом.

Аналіз останніх досліджень і публікацій. Загалом спостерігається відродження інтересу до відображення параметричних характеристик об'єкта у мовній картині світу (Т. Хорькова, I. Кузіна, Х. Клак Герберт, М. Бургес, С Тайлер), вивчення лексико-семантичних розрядів прикметників (В. Жирмунський, В. Павлов, А. Шрамм), зокрема прикметників на позначення загального розміру (П. Цикорева, Р. Усманов, Л. Букштайн Фред, Се Чжигоу).

Ознака «загальний розмір» служить для передачі найважливішої інформації стосовно просторової конфігурації та параметрів об'єктів. Цей параметр вміщає дані як про сукупний розмір об'єкта, так і про його лінійні ознаки, що подають характеристику з різним ступенем деталізації на основі співвіднесення їх параметрів 3 осями тривимірного простору: довжини, ширини, висоти.

Науковці зазначають, що сприйняття та обробка інформації про навколишній світ здійснюється людиною на основі власного досвіду. Відтак передбачуваний розмір об'єкта уявно моделюється під час розуміння мови, ситуації, описаної в тексті [Wassenburg 2016 : 493].

Прийняті лексикографами вимоги до словникової дефініції базуються на дещо спрощеному логічному підході, згідно з яким лексичне значення слова, як і його відображення у словниковому тлумаченні, має бути представлене через певний мінімальний набір ознак відповідного поняття, достатніх для того, щоб можна було відрізнити одне слово від іншого, причому цей набір не повинен бути надлишковим (в нього повинні входити ті ознаки, які разом забезпечують розуміння побудованого тлумачення). А в тлумаченнях назв об'єктів реального світу реалізувати ці умови виявляється вкрай складно, навіть якщо йдеться про закриті тематичні групи [Жуйкова $2021: 55]$.

Мета статті - виявити параметр «загальний розмір» у текстах дефініцій зоонімів, визначити способи його вираження та встановити ступінь інформативної достатності відповідного опису представників тваринного світу.

Виклад основного матеріалу й обгрунтування отриманих результатів дослідження. Пропоноване дослідження акцентує увагу на потребі докладного розгляду питання інтерпретації параметра «загальний розмір» у текстах дефініцій зоонімів, вибраних із трьох тлумачних словників сучасної англійської мови, a came: "The Oxford Advanced Learner's Dictionary of Current English" (OALDCE), "The Collins COBUILT English Dictionary for Advanced Learners" (CCEDAL) та "The Longman Dictionary of Contemporary English" (LDOCE).

Проаналізувавши масив словникових дефініцій, загальною кількістю 767 мікротекстів (LDOCE - 282, CCEDAL - 221, OALDCE 264), зазначимо, що автори кожного із видань використовують кілька способів указівки цілісних розмірних характеристик тварини або ж опускають цей параметр взагалі.

Категорія «загальний розмір» відбиває різні просторові напрями можливого прояву цієї ознаки. В мові цей процес здійснюється за рахунок параметричних прикметників, які здатні формувати опозитивні семантичні пари. Параметр «загальний розмір» авторами досліджуваних лексикографічних видань прийнято вводити на початку дефініції, найчастіше за допомогою прикметників "small" або "large", формуючи таким способом цілісне враження про тварину, наприклад:

armadillo 'панцерник' "a small animal that has a shell made of hard material, and lives in parts of North and South America" [LDOCE 2005 : 67].

bear 'ведмідь' "large, heavy animal with thick fur" [OALDCE 1982: 69].

Процентне співвідношення дефініцій із прикметником "small” та "large" в опрацьованих словниках вказане відповідно: LDOCE - 19\% / $20 \%$, CCEDAL- $15 \% / 19 \%$, OALDCE- $17 \% / 15 \%$. 
Цікавим фактом $\epsilon$ те, що багаточисельним виявляється набір тлумачень, у яких параметр «загальний розмір» 3 певних причин не вказано. Наприклад, цілком доцільно опускати таку ознаку, визначаючи добре відому людині тварину, наприклад, пса: $\operatorname{dog}$ "A $\operatorname{dog}$ is a very common four-legged animal that is often kept by people as a pet or to guard or hunt. There are many different breeds of dog" [CCALED 2001 : 453]. Така модель опису буде типовою для усіх одомашнених чи близьких для людини тварин.

Однак дефініція зооніма “okapi” 'окапі', що $\epsilon$ швидше маловідомою твариною, малоінформативна і не вміщає жодних даних про розмір: "rare forest ruminant animal of Central Africa" [OALDCE : 79]. Здогадатися, як виглядає тварина, за таким описом вкрай складно.

Втім, число дефініцій без параметра «загальний розмір» дивує кількісним показником, для порівняння наведемо визначене співвідношення: LDOCE - 39\%, CCEDAL - 38\%, OALDCE $-46 \%$.

Ще одним способом представлення величини тварини виступає вказівка на подібність із іншою твариною, яка іноді може комбінуватися iз параметричним прикметником, очевидно 3 метою коригування ознаки «загальний розмір». Для прикладу наведемо такі дефініції:

donkey 'віслюк' "a grey or brown animal like a horse, but smaller and with long ears" [LDOCE 2005 : 464].

buffalo 'бізон' "an African animal similar to a large cow with long curved horns" [LDOCE 2005: 191].

fox 'лис' "A fox is a wild animal which looks like a dog and has reddish-brown fur, a pointed face and ears, and a thick tail. Foxes eat smaller animals" [CCALED $2001: 624]$

Такі порівняльні конструкції часто комбінуються з прикметниками "small" та "large", що дозволяє розширити уявлення про зовнішній вигляд відповідного представника світу фауни, орієнтуючись на приблизний розмір подібної прототипової тварини. Для прикладу розглянемо дефініцію chamois 'козиця', “small goat-like animal that lives in the high mountains of Europe and SW Asia" [OALDCE 1982 : 137]. 3 опису стає відомо, що козиця - невелика та схожа на козу тварина, де інформація про козу значно полегшує сформувати образ в уяві читача.
Підгрунтям усіх вимірювальних стратегій $\epsilon$ процес порівняння або зіставлення одного об'єкта чи ознаки з іншим, нормативним, прототиповим або еталонним образом. Це дозволяє віднести розглянуті конструкції розміру до конструкцій з точкою відліку. Оскільки людина $\epsilon$ мірилом усіх речей, вважаємо стратегії виміру глибоко антропоцентричними. Крім того, спостерігаємо, що параметризація розміруздійснюється людиною за певною «градуальною семантичною шкалою, центром якої є певне еталонне уявлення про норму параметричної ознаки об' єкта» [Zhiguo 2014: 154]. Відтак спостерігаємо використання ступенів порівняння прикметників: whale 'кит' "Whales are very large mammals that live in the sea" [CCALED 2001: 1778]

wolfhound 'вовкодав' “a type of extremely large dog" [LDOCE 2005 : 1897].

elk 'вапіті' «one of the largest kinds of living deer, found in $N$ Europe, $N$ Asia, and (called a moose) N America» [OALDCE 1982 : 280].

Усі вживані у словниках «розмірні» конструкції використовуються для вказівки на приблизний розмір об'єкта, який порівнюється 3 добре відомим всім членам мовного колективу стандартом, який до того ж може мати варіативний характер - розглядатися на тлі усіх представників тваринного світу або в межах певного таксономічного рангу. Для точних вказівок у сучасній англійській мові використовується метрична або англійська система мір, проте в жодну із проаналізованих дефініцій не внесено таких даних.

Загалом об'єкт повинен володіти набором певних властивостей, щоб бути охарактеризованим конкретним прикметником (тією ознакою, яка переважає). Найбільш прототипові випадки використання укорінені у свідомості носіїв мови, тому не потребують окремих зусиль для ідентифікації відповідного фаунопредставника. Але розмитість певної ознаки, а подекуди ії відсутність, збивають читача зі шляху формування адекватного уявлення про той чи інший об'єкт реального світу.

Висновки. Зважаючи на опрацьований матеріал, можемо твердити про доволі непростий інтерпретаційний процес, зумовлений непослідовністю у наборі семантичних компонентів, відсутністю ознак, важливих для національної мовної свідомості, вузькістю денотативної 
дефініції, яка дозволяє створити чіткий образ тварини. Проведений аналіз переконує у необхідності внесення істотних змін у структуру тлумачень одиниць конкретної іменної лексики, виразної чіткості та уніфікованості.

Категорія розміру $\epsilon$ категорією базового рівня, яка вербалізується в мові прикметниками. Розмір - невіддільна ознака об'єкта, на відміну від його фізичних характеристик, таких як, наприклад, колір, запах, смак тощо, тому $\epsilon$ важливим атрибутом. Параметр «загальний розмір» належить до семантично градуйованих категорій: в основі іiі формування лежать параметричні (градуйовані) концепти, що співвідносяться 3 певною мірною шкалою, яка також орієнтована на приблизну норму. Загальна специфіка параметричних прикметників полягає в їх якісно-кількісному синкретизмі та здатності виражати як об'єктивну оцінку, тобто базується на стереотипних уявленнях людей про тварину, так і суб'єктивну оцінку людини, що теж може стати перепоною на шляху інтерпретаційної діяльності.

Виконана розвідка не вичерпує всього комплексу питань, пов'язаних із лексикографічним описом груп конкретної іменної лексики. Поза увагою залишається чимало аспектів та принципів дефініціювання цілих систем лексичних одиниць. Перспективи подальших досліджень убачаємо в розробці уніфікованого підходу до лексикографічного опису зоонімічної лексики та порівняльному вивченні параметричних прикметників, що дозволить виявити як універсальні характеристики, засновані на спільності людського мислення, категоризації та концептуалізації дійсності, так і унікальні явища, що відбивають особливості менталітету окремих народів, національних культур та традицій.

\section{ЛІТЕРАТУРА}

1. Жуйкова М. В., Йодловская А. И. К проблеме построения словарных толкований конкретной именной лексики (флора и фауна). Вопросы лексикографии, 2021. № 19. С. 52-74. DOI: 10.17223/22274200/19/3.

2. Collins COBUILT English Dictionary for Advanced Learners. 3d edition. India : Thomson Press, 2001. 1824 p.

3. Hornby A. S. The Oxford Advanced Learner's Dictionary of Current English. V. 1, 2. M. : Pyc. Яз., 1982.

4. The Longman Dictionary of Contemporary English. New edition. P. Cm. Pearson Education, 2005. 1950 p.

5. Wassenburg S. I., Koning de B. B., Bos L. T., Van der Schoot M. Size does matter: Implied object size is mentally simulated during language comprehension. Discourse processes. 54 (7), 2016. Pages: 493-503.

6. Zhiguo Xie. Where is the Standard? An Analysis of Size Adjectives as Degree Modifiers at the Semantic Pragmatic Interface. Language and Linguistics, 2014. Volume: 15. Issue: 4. Pages: 513-538.

\section{REFERENCES}

1. Zhuikova M. V., Yodlovskaia A. I. (2021) K probleme postroieniia slovarnyh tolkovanii konkretnoi imennoi leksyky (flora i fauna) [On the problem of constructing dictionary definitions of specific nominal lexis (flora and fauna)]. Voprosy lexicografi, № 19, pp. 52-74. DOI: 10.17223/22274200/19/3 (in Russian)

2. Collins COBUILT English Dictionary for Advanced Learners (2001) 3d edition. India : Thomson Press. 1824 p.

3. Hornby A. S. (1982) The Oxford Advanced Learner's Dictionary of Current English. V. 1, 2. M. : Rus. Yaz.

4. The Longman Dictionary of Contemporary English (2005) New edition. P. Cm. Pearson Education. 1950 p.

5. Wassenburg S. I., Koning de B. B., Bos L. T., Van der Schoot M. (2016) Size does matter: Implied object size is mentally simulated during language comprehension, Discourse processes 54 (7), pp. 493-503.

6. Zhiguo Xie (2014) Where is the Standard? An Analysis of Size Adjectives as Degree Modifiers at the Semantic Pragmatic Interface. Language and Linguistics. Volume: 15, Issue: 4, pp. 513-538. 


\title{
A. V. SHEVCHUK
}

Candidate of Philological Sciences, Associate Professor at the Department of Foreign and Ukrainian Philology, Lutsk National Technical University, Lutsk, Ukraine

E-mail: a.shevchuk@lutsk-ntu.com.ua

https://orcid.org/0000-0002-5005-3800

\author{
A. I. YANOVETS \\ Candidate of Philological Sciences, Associate Professor, \\ Associate Professor at the Department of Foreign and Ukrainian Philology, \\ Lutsk National Technical University, Lutsk, Ukraine \\ E-mail:angelikayanovec@lutsk-ntu.com.ua \\ https://orcid.org/0000-0002-1626-5244
}

\section{“OVERALL SIZE" PARAMETER IN LEXICOGRAPHICAL DESCRIPTION OF ZOONYMS}

The proposed scientific research is devoted to the interpretation of the "overall size" parameter in the definitions of zoonymic lexis, selected from three authoritative lexicographic sources of Modern English. It was found that presenting the spatial characteristics of the objects of the material world at the linguistic level, parametric adjectives are characterized, on the one hand, by the simplicity of interpretation and determination of their meaning as empirical adjectives, which reflect the features of objects that are perceived perceptually. It makes their semantics relatively transparent and stable. On the other hand, the lack of clear fixed limits of their use, clearly defined standards of comparative constructions allows for their further semantic development and deviation in the interpretation of the dimensional characteristics of objects. Therefore, the identification of the peculiarities of the use of parametric adjectives and lexical constructions that denote the overall size of real-world reference objects is an urgent problem both from the point of view of the theoretical and from the point of view of the practical aspects of the lexicographic representation of lexemes-zoonyms in different types of linguistic dictionaries. In particular, it is indicated that zoonym definitions introduce information about the overall size of the animal at the beginning of the dictionary definition. In this case, the adjectives "large" and "small" have the highest frequency rates, indicating the general impression of the animal. The use of comparative constructions is also observed, in which we receive an indication of a similar animal, which simplifies the identification of the referent by the reader, or additionally introduces data on the size ratio. In a large number of zoonym definitions, the parameter "overall size" is omitted. However, these are mainly well-known representatives of the fauna world, which are usually not difficult to recognize by humans.

The article discusses the issues of the parametric norm, standard, as well as the grading of adjectives. In general, it was determined that the proposed methods of lexicographic description of zoonymic vocabulary require improvement and a unified approach, since the authors of dictionaries often do not follow the principles of adequacy and sufficiency, which leads to difficulties in interpreting the information presented in a dictionary entry.

Key words: lexicography, explanatory dictionary, zoonym, adjective, "overall size". 